\title{
Norman L Jones Award
}

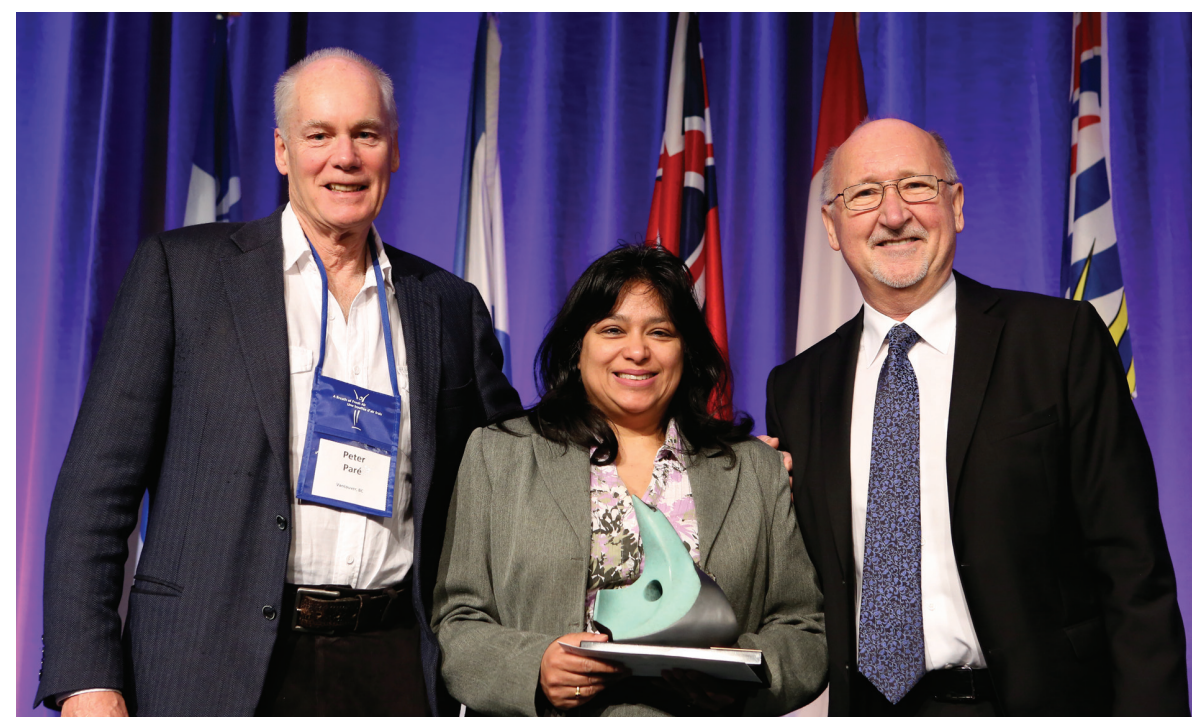

Dr Peter Paré (left), Editor-in-Chief and Robert Kalina (right), Publisher of the Canadian Respiratory Journal, with Dr Anna Banerji, who accepted the 2015 Dr Norman L Jones Award on behalf of the authors of 'The real-life effectiveness of palivizumab for reducing hospital admissions for respiratory syncytial virus in infants residing in Nunavut' (A Banerji, V Panzov, M Young, BE Lee, M Mamdani, BL Giles, M Dennis, J Morel, D Bisson, BA Paes, C Hui, J Mahoney, Can Respir J 2014;21[3]:185-189). This award, sponsored by Pulsus Group Inc, was presented at the recent Canadian Respiratory Conference held in Ottawa, Ontario, and carries with it a cheque in the amount of $\$ 1,000$ and a piece of Canadian art.

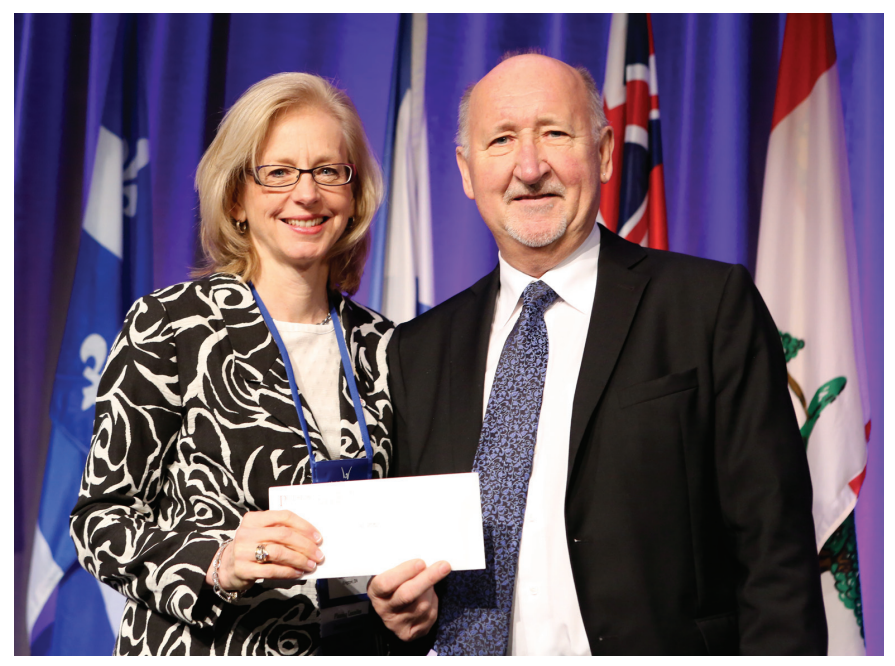

Robert Kalina (right), Publisher of the Canadian Respiratory Journal presents a cheque to Dr Diane Lougheed, President of the Canadian Thoracic Society (CTS). Each year, Pulsus Group gives a percentage of revenues associated with the Journal to the CTS. As official journal of the CTS, the Canadian Respiratory Journal serves as the key provider for publishing Society guidelines and resource information critical to their members and Canadian physicians. 


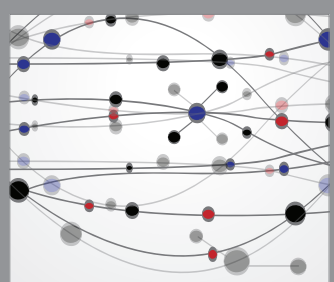

The Scientific World Journal
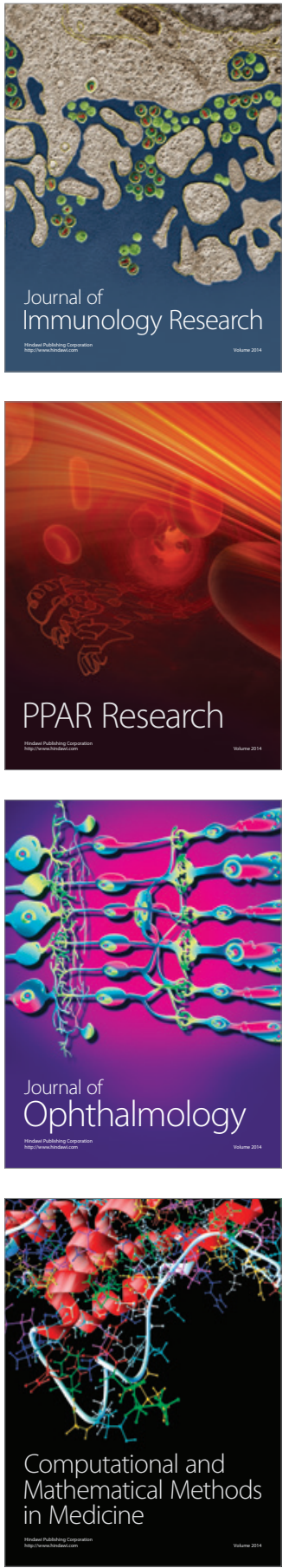

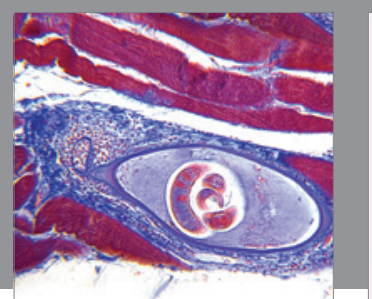

Gastroenterology Research and Practice

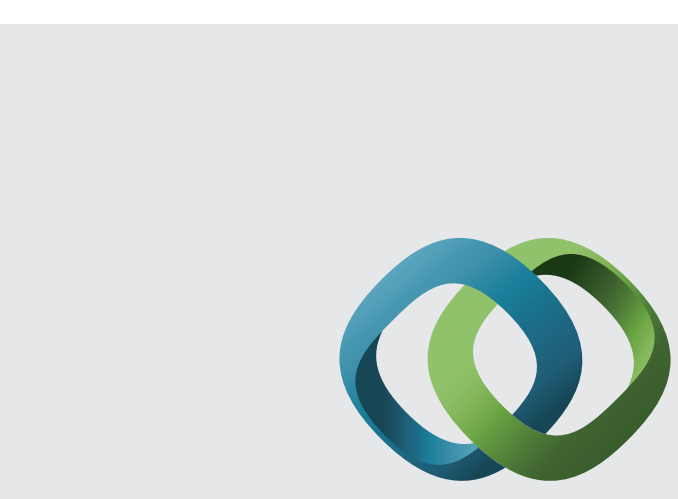

\section{Hindawi}

Submit your manuscripts at

http://www.hindawi.com
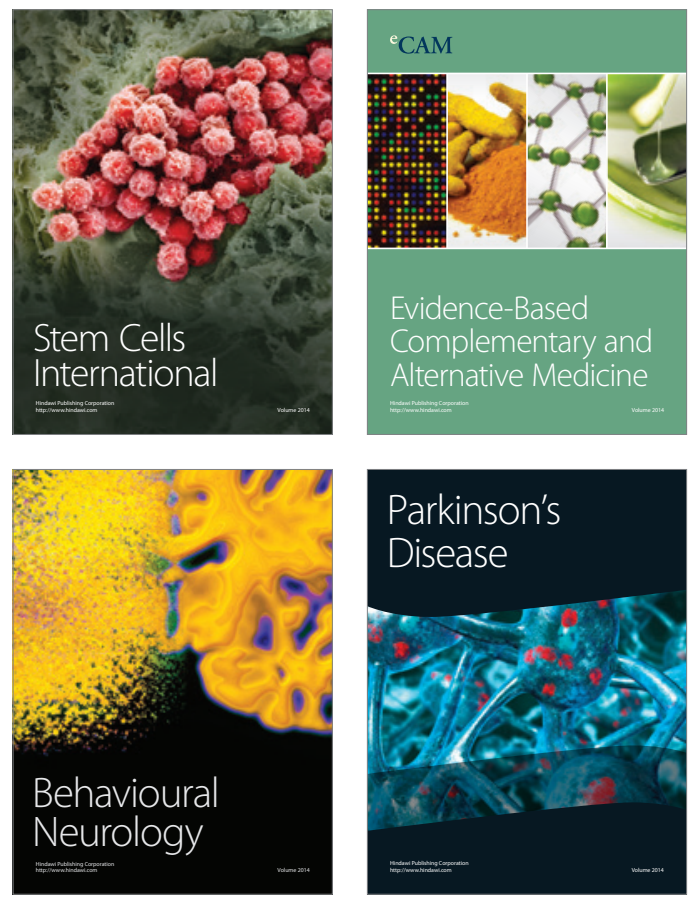
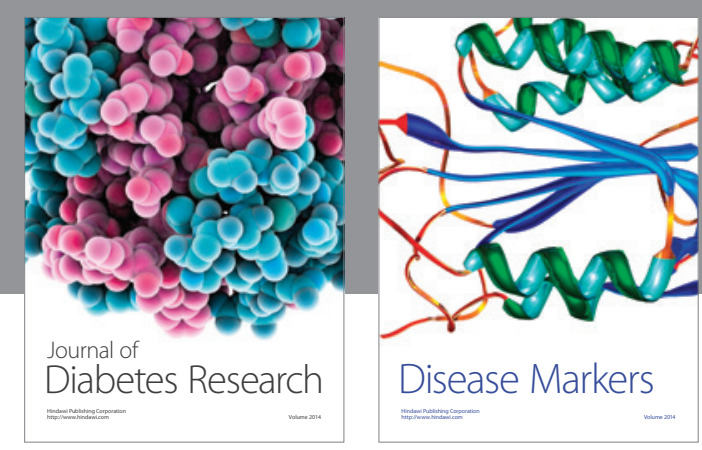

Disease Markers
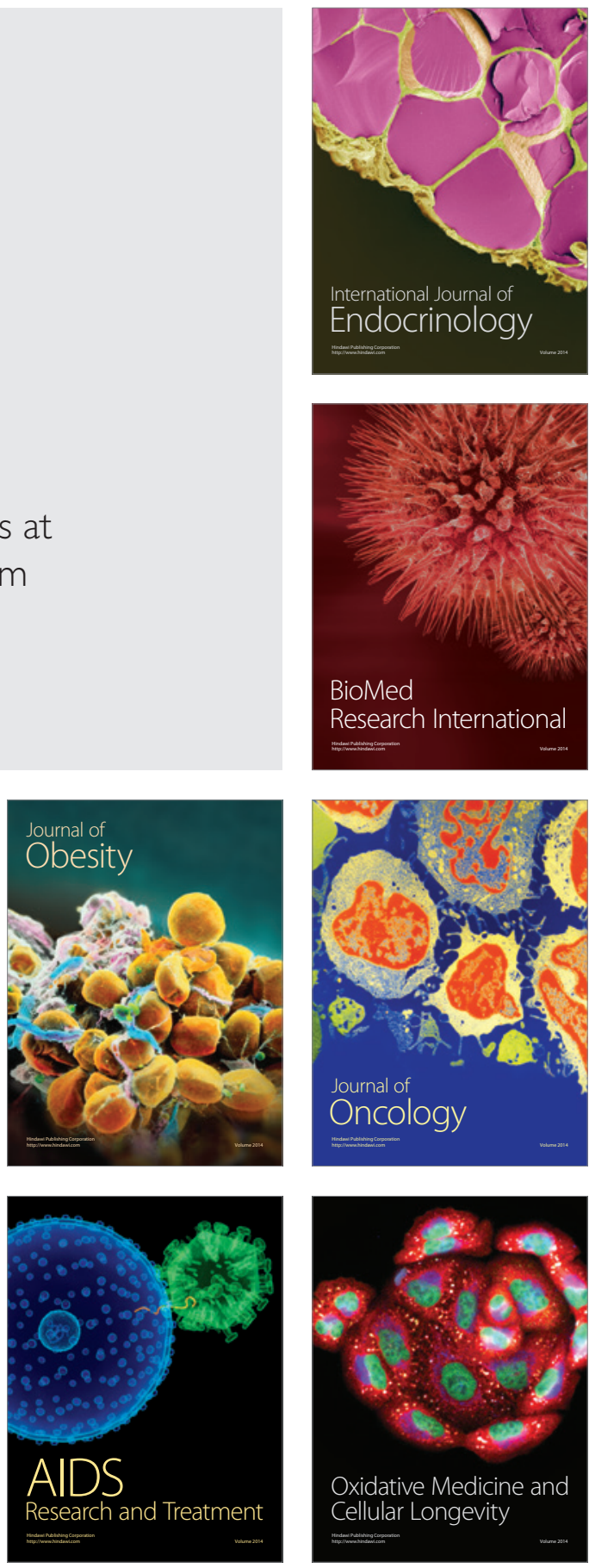